\title{
PENGARUH WAKTU AKTIVASI TERHADAP SIFAT FISIS DAN ELEKTROKIMIA SEL SUPERKAPASITOR DARI SABUT PINANG
}

\author{
Retno Handayani*, Erman Taer \\ Jurusan Fisika, Universitas Riau \\ *E-mail korespondensi: rtnohandayani@gmail.com
}

\begin{abstract}
The Carbon electrodes made from areca husk biomass materials have been successfully prepared and characterized. Preparation of carbon electrodes start with the pre-carbonization process, destruction of pre-carbon samples by using Ball Milling and sieving carbon powder for resulting particle size of <53 $\mu \mathrm{m}$. Pre-carbonized powder is chemically activated using a $0.5 \mathrm{M} \mathrm{KOH}$ activator and continued by pellet forming by using Hydraulic Press. The carbonization process was carried out at a temperature of $600{ }^{\circ} \mathrm{C}$ using $\mathrm{N}_{2}$ gas followed by physical activation by using $\mathrm{CO}_{2}$ gas with a temperature of $900{ }^{\circ} \mathrm{C}$ for 1.5 hours, 2 hours and 2.5 hours. Physical properties analyzed include density, morphological structure and elemental content. The electrochemical properties were analyzed using the cyclic voltammetry (CV) method. The best density analysis result after carbonization-activation is 0.664 in SP-2.5 sample. The highest specific capacitance as high as $17.9 \mathrm{~F} / \mathrm{g}$ found in the SP-1.5 sample.
\end{abstract}

Keywords: Carbon electrode, Chemical activation, Areca husk

\begin{abstract}
ABSTRAK
Elektroda karbon dari bahan biomassa sabut pinang telah berhasil dibuat dan dikarakterisasi. Pembuatan elektroda karbon dimulai dengan proses pra-karbonisasi, penghancuran sampel pra-karbon menggunakan mortar-Ball Milling dan pengayakan serbuk karbon dengan ukuran partikel <53 $\mu \mathrm{m}$. Serbuk ter pra-karbonisasi diaktivasi kimia menggunakan aktivator $\mathrm{KOH}$ dengan konsentrasi 0,5M. Serbuk ter-prakarbonisasi yang telah diaktivasi kimia dicetak dengan menggunakan Hydraulic Press untuk membentuk pelet. Proses karbonisasi dilakukan pada suhu $600^{\circ} \mathrm{C}$ menggunakan gas $N_{2}$ dan aktivasi fisika menggunakan gas $\mathrm{CO}_{2}$ dengan suhu $900^{\circ} \mathrm{C}$ selama waktu 1,5 jam, 2 jam dan 2,5 jam. Sifat fisis yang dianalisa meliputi densitas, struktur morfologi dan kandungan unsur. Sifat elektrokimia dianalisa menggunakan metode cyclic voltammetry $(\mathrm{CV})$. Hasil analisa densitas terbaik setelah karbonisasi-aktivasi adalah 0,664 pada sampel SP-2.5. Spesifik kapasitansi tertinggi adalah 17,9 F/g terdapat pada sampel SP-1.5.
\end{abstract}

Kata kunci: Elektroda karbon, Aktivasi kimia, Sabut pinang

Diterima 08-07-2019| Disetujui 25-09-2019| Dipublikasi 31-10-2019

\section{PENDAHULUAN}

Superkapasitor atau kapasitor elektrokimia lapis ganda (EDLC) dapat dijadikan sebagai perangkat penyimpanan energi yang baru. Kelebihan edlc meliputi siklus hidup yang lama, waktu charge-discharge cepat, rapat daya tinggi, karakteristik temperatur yang bagus, dan aman digunakan [1]. Secara luas juga telah digunakan dalam berbagai bidang elektronik seperti system telekomunikasi digital, computer, pulse laser system, hybrid electrical vehicle, dan sebagainya [2]. Performa dari material sangat bergantung pada material elektroda yang memiliki luas permukaan yang tinggi dan keseragaman pori [3], seperti bahan karbon. Salah satu bahan asal karbon yang mudah ditemui dengan harga yang relatif lebih murah adalah bahan-bahan biomassa seperti sisa-sisa pertanian dan perkebunan. 
Buah pinang segar mengandung biomassa sabut pinang lebih dari setengah berat total massa yaitu $60 \%$ sampai $80 \%$. Menurut data badan statistik tahun 2015 produksi buah pinang mencapai angka 47,1 ton setiap tahunnya dan akan meningkat pada tahun berikutnya. Secara kimia sabut buah pinang mengandung flavonoid, alkaloid, hemiselulosa, selulosa dan pektin [4]. Komposisi material selulosa yang terdapat dalam sabut pinang yaitu 70\% [5]. Kandungan selulosa yang tinggi dapat mengindikasikan sabut pinang merupakan bahan asal pembuatan elektroda karbon yang baik.

Bahan asal pembuatan elektroda karbon aktif dari sabut pinang diperoleh dengan tahapan karbonisasi dan aktivasi bahan biomassa. Tahapan karbonisasi dilakukan dalam lingkup gas $\mathrm{N}_{2}$ pada suhu $600^{\circ} \mathrm{C}$. Tahapan aktivasi dilakukan dengan dua cara yaitu aktivasi kimia dan aktivasi fisika. Aktifasi kimia pada penelitian menggunakan bahan pengaktif yaitu kalium hidroksida $(\mathrm{KOH})$. Bahan pengaktif $\mathrm{KOH}$ dapat meningkatkan kekuatan serat dari sabut pinang [6]. Aktivasi fisika dilakukan dalam lingkup gas $\mathrm{CO} 2$ pada suhu $900^{\circ} \mathrm{C}$ dengan waktu yang divariasikan.

\section{METODE PENELITIAN}

Sabut pinang didapatkan dari pengumpul buah pinang. Sabut pinang dibersihkan dan ditumbuk-tumbuk agar serat yang didapatkan lebih bagus. Sampel sabut pinang kemudian dikeringkan dibawah sinar matahari dan dilanjutkan pengeringan dengan oven pemanas bersuhu $110^{\circ} \mathrm{C}$, masing-masing selama $2 \times 24$ jam. Sampel yang telah kering dilanjutkan ke proses pra-karbonisasi dengan memasukkan sampel kedalam oven selama 2,5 jam bersuhu $250^{\circ} \mathrm{C}$. Sampel yang telah dipra-kabonisasi dihancurkan dengan ball milling dan diayak dengan ukuran partikel $<53 \mu \mathrm{m}$. Serbuk prakarbonisasi kemudian diaktivasi kimia dengan bahan pengaktif $\mathrm{KOH} 0,5 \mathrm{M}$ selama 2 jam dan dikeringkan di oven pengering. Serbuk aktivasi yang telah kering kemudian dicetak dengan Hidraulic press berbentuk monolit. Serbuk tang telah berbentuk monolit kemudian dikarbonisasi dan aktivasi fisika pada suhu $600^{\circ} \mathrm{C}$ dan $900^{\circ} \mathrm{C}$ dengan waktu yang divariasikan. Masing-masing sampel kemudian dilakukan pengujian sifat fisika dan elektrokimia.

\section{HASIL DAN PEMBAHASAN}

\section{Analisa Sifat Fisis densitas}

Tabel 1. Grafik perbandingan densitas elektroda

\begin{tabular}{lll}
\hline $\begin{array}{l}\text { Kode } \\
\text { sampel }\end{array}$ & $\begin{array}{l}\text { Sebelum } \\
\text { karbonisasi }\end{array}$ & $\begin{array}{l}\text { Setelah } \\
\text { karbonisasi }\end{array}$ \\
\hline SP-1.5 & 1.107 & 0.82 \\
SP-2.0 & 1.129 & 0.763 \\
SP-2.5 & 1.081 & 0.664 \\
\hline
\end{tabular}

Tabel 1 menunjukkan data perubahan densitas elekroda karbon sebelum dan setelah karbonisasi-aktivasi. Densitas elektroda karbon setelah karbonisasi-aktivasi jauh lebih kecil dibandingkan sebelum karbonisasi. Hal ini dikarenakan penambahan gas $\mathrm{N}_{2}$ dan $\mathrm{CO}_{2}$ membuat partikel dari elektroda karbon rusak membentuk pori yang lebih halus. Penambahan waktu aktivasi fisika terhadap densitas elektroda karbon membuat densitas elektroda karbon semakin susut. Susut densitas paling tinggi terdapat pada sampel SP-2.5 sebesar $42 \%$ hampir setengah densitas awal. Susut densitas yang tinggi dikarenakan berkurangnya zat pengotor pada elektroda karbon. Susut densitas yang tinggi juga dipengaruhi waktu aktivasi, semakin lama aktivasi menyebabkan penguapan bahan selain karbon sehingga menyebakan pembentukan pori-pori baru pada sampel. Pori-pori baru yang banyak terbentuk mengakbatkan porositas elektroda karbon semakin besar

\section{Analisa Sifat Fisis Scanning electron Microscopy}

Karakterisasi struktur morfologi atau SEM untuk elektroda karbon masing-masing sampel pada perbesaran 1000 kali ditunjukkan pada Gambar 1. Morfologi permukaan sampel 
terdiri dari partikel dan pori-pori dalam skala mikrometer dengan bentuk yang tidak teratur. Gambar 1.a menunjukkan sampel SP-1.5 dengan morfologi permukaan sampel didominasi oleh partikel-pertikel yang berukuran besar dan tidak seragam. Gambar 1.b menunjukkan sampel SP-2.0 dengan morfologi permukaan sampel terdiri dari partikel-partikel dan juga terbentuk pori baru. Ukuran partikel yang terbentuk pada sampel ini lebih kecil dibanding sampel SP-1.5. Poripori baru yang terbentuk berukuran kecil sekitar 600-1100 nm. Gambar 1.c menunjukkan sampel SP-2.5 dengan morfologi permukaan sampel terdiri dari partikel yang lebih kecil dibanding sampel SP-1.5 dan SP2.0. Pori-pori yang terbentuk pada sampel ini berukuran sekitar 3000-5000nm. Penambahan besar ukuran pori disebabkan karena terkikisnya permukaan pori karena lamanya waktu aktivasi.

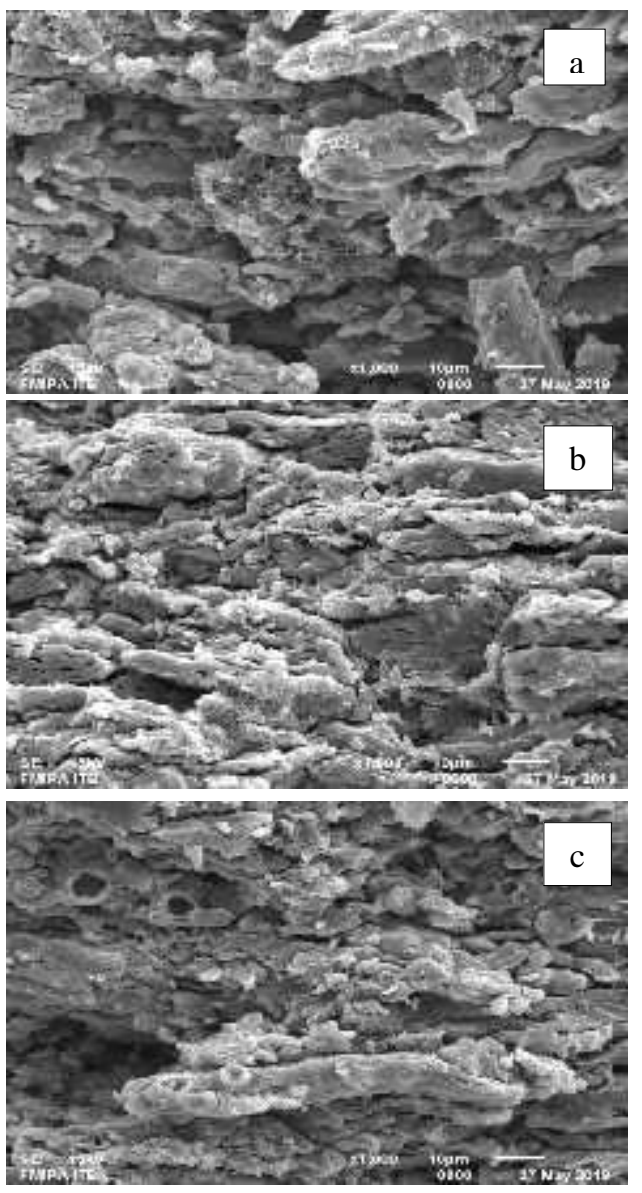

Gambar 1. Hasil karakterisasi SEM sampel SP perbesaran 1000 kali untuk (a) SP-1.5 (b) SP-2.0 dan (c) SP-2.5.

\section{Analisa Sifat Fisis Energy Dispersif X-Ray}
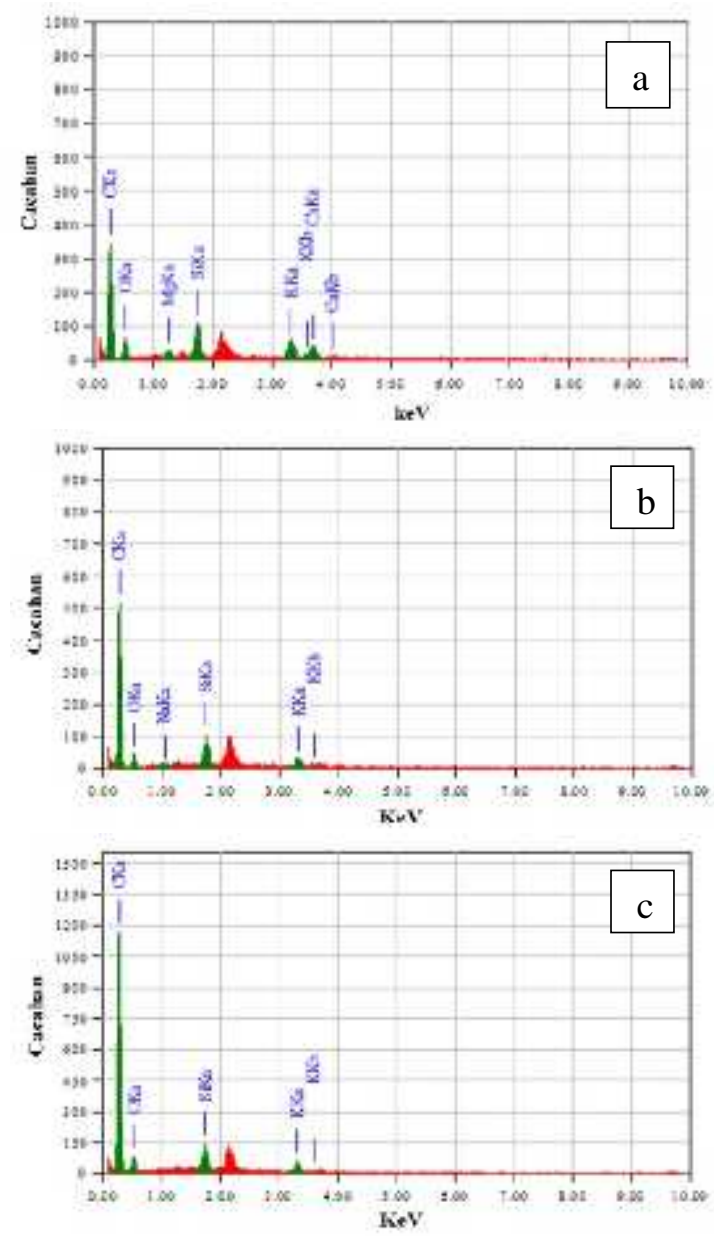

Gambar 2. Kurva karakterisasi energy dispersif sinar- $x$ masing-masing sampel (a) SP-1.5 (b) SP-2.0 dan (c) SP-2.5.

Gambar 2 menunjukkan hasil karakterisasi dispersif sinar-x yang bertujuan untuk mengetahui kandungan unsur yang ada pada sampel elektroda sabut pinang. Gambar 2.a menunjukkan banyaknya kandungan unsur selain karbon yang terdapat pada sampel, seperti oksigen, magnesium, silika, kalsium dan kalsium. Jumlah unsur karbon berkisar 350 cacahan. Gambar 2.b menunjukkan banyaknya kandungan unsur selain karbon yang sudah mulai berkurang, seperti oksigen, natrium, silika dan kalium. Jumlah kandungan karbon berkisar 500 cacahan lebih banyak dari sampel SP-2.0. Gambar 2.c menunjukkan banyaknya kandungan unsur selain karbon sudah berkurang, tidak sebanyak sampel SP1.5 dan SP-2.0 yaitu oksigen, silika dan kalium. Semakin lama waktu aktivasi 
membuat sampel selain karbon semakin berkurang. Jumlah kandungan karbon pada sampel SP-2.5 memiliki jumlah tertinggi yaitu 1150 cacahan, hal ini dikarenakan penambahan waktu aktivasi membuat kandungan unsur karbon semakin meningkat.

Analisa sifat elektrokimia sel superkapasitor (Cyclic Voltametry)

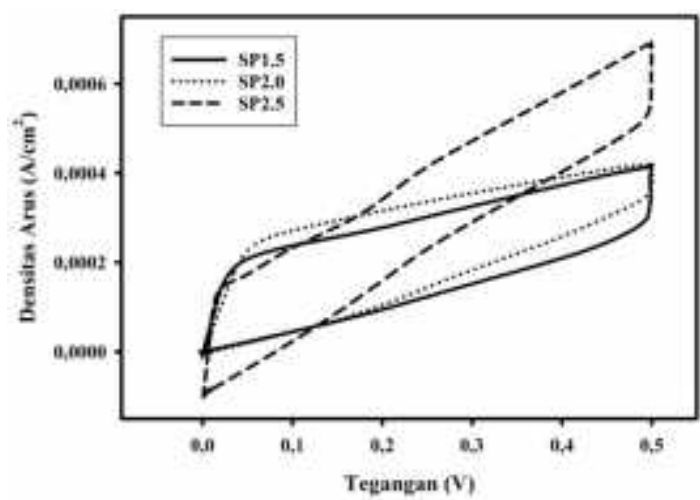

Gambar 3. Cyclic voltammetry elektroda karbon dari sabut pinang pada masing-masing sampel.

Metode cyclic voltammetry (CV) digunakan untuk melakukan pengukuran sifat elektrokimia sel superkapasitor. Gambar 3 menampilkan kurva hubungan antara tegangan terhadap arus. Sampel SP-1.5 meperlihatkan lebar daerah Ic-Id paling besar diantara sampel lainnya.

Kapasitansi spesifik yang dihasilkan sampel SP-1.5, SP-2.0 dan SP-2.5 yaitu 17,9 F/g, 16,7 F/g dan 16,47 F/g. Semakin lama waktu aktivasi kapasitansi yang dihasilkan semakin menurun. Penurunan kapasitansi dikarenakan lamanya waktu aktivasi sehingga membuat pori-pori yang terbentuk semakin terkikis dan lebar. Pori-pori ini juga menjadi rusak, sehingga kapasitansi yang dihasilkan menurun.

\section{KESIMPULAN}

Hasil dan pembahasan menunjukkan waktu aktivasi 1,5 jam merupakan waktu terbaik untuk pembuatan elektroda karbon dari sabut pinang. Penambahan waktu aktivasi meningkatkan persentase susut densitas dan jumlah kandungan karbon yang dihasilkan. Semakin lama aktivasi membuat bahan pengotor pada sampel berkurang.

\section{UCAPAN TERIMAKASIH}

Penulis mengucapkan terimakasih kepada Kementrian Riset dan Teknologi atas bantuan pendanaan melalui projek PD tahun 2019 dengan nomor kontrak 729/UN.19.5.1.3/ PT.01.03/2019.

\section{REFERENSI}

1. Zhang. C., Zhu. X., Cao. M., Li. M., Li. N et al (2016). Hierarchical Porous Carbon Materials Derived from Sheep Manure for High-Capacity Supercapacitor. Chemsuschem, 9, 932-937.

2. Zhu, Z., Hu, H., Li, W., and Zhan, X., (2007). Resovcinol formaldehyde based porous carbon as an electrode material for supercapasitor. Carbon 5(1) : 160-165.

3. Pang, E., Hao, Y., Sun, Y., and Lin, K. (2016). Differential variation patterns between hubs and bottlenecks in human protein-protein interaction networks. BMC Evol. Biol. 16:260.

4. Cyriac, M., Pai. V., Varghese, 1., Shantaram, M., Jose, M. (2012). Antimicrobial Properties of Areca Catechu (Areca Nut) Husk Extracts Againts Commom Oral Pathogents. International Journal Research in Ayuvedic Pharmaceutical. 3(1), 81-84

5. Panjaitan, RR. 2008. Pengembangan Pemanfaatan Sabut Pinang untuk Pembuatan Asam Oksalat. Berita Litbang Industri Media Publikasi dan komunikasi Peneliti Industri. 39(1)

6. Rekha. V. B., Ramachandralu. K., S. V. (2015). International Journal of Pharmtech Research. 8(4), 521-530

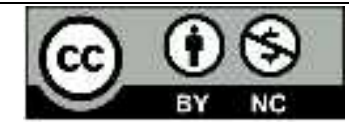

Artikel ini menggunakan lisensi Creative Commons Attribution 4.0 International License 